\title{
Volcanological processes and their effect on diamond distribution in the Letšeng Satellite Pipe, Lesotho
}

\author{
Claire E. Palmer ${ }^{1,2}$, John D. Ward ${ }^{2}$, Johann Stiefenhofer ${ }^{3}$ and T. Keith Whitelock ${ }^{4}$ \\ ${ }^{1}$ CSIR Natural Resources and the Environment, Johannesburg, South Africa \\ ${ }^{2}$ Gem Diamond Technical Services (Pty) Ltd, Johannesburg, South Africa \\ ${ }^{3}$ De Beers Group Services (Pty) Ltd, Johannesburg, South Africa \\ ${ }^{4}$ Letšeng Diamonds (Pty) Ltd, Maseru, Lesotho
}

The Letšeng Diamond Mine is situated at 3,100 m above sea level in the Maloti Mountains of Lesotho, a small land-locked country in southern Africa (Figure 1). The mine consists of two Group 1 kimberlite pipes: the Main Pipe (17.2 ha in size) and the Satellite Pipe (5.2 ha in size). These two pipes erupted through the cover sequence of Jurassic-age Drakensberg Group flood basalts $91 \mathrm{Ma}$ ago. Formal mining of the low grade (1-3 carats per hundred tonnes, cpht) Letšeng kimberlites occurred initially from 1977 to 1982, producing c. 273,000 carats (Whitelock, et al., 2004). Subsequently, the mine re-opened in late 2003 and had yielded c. 241,000 carats by the end of May 2008, including twenty-four +100 carat (ct) diamonds (Bowen, et al., 2008).

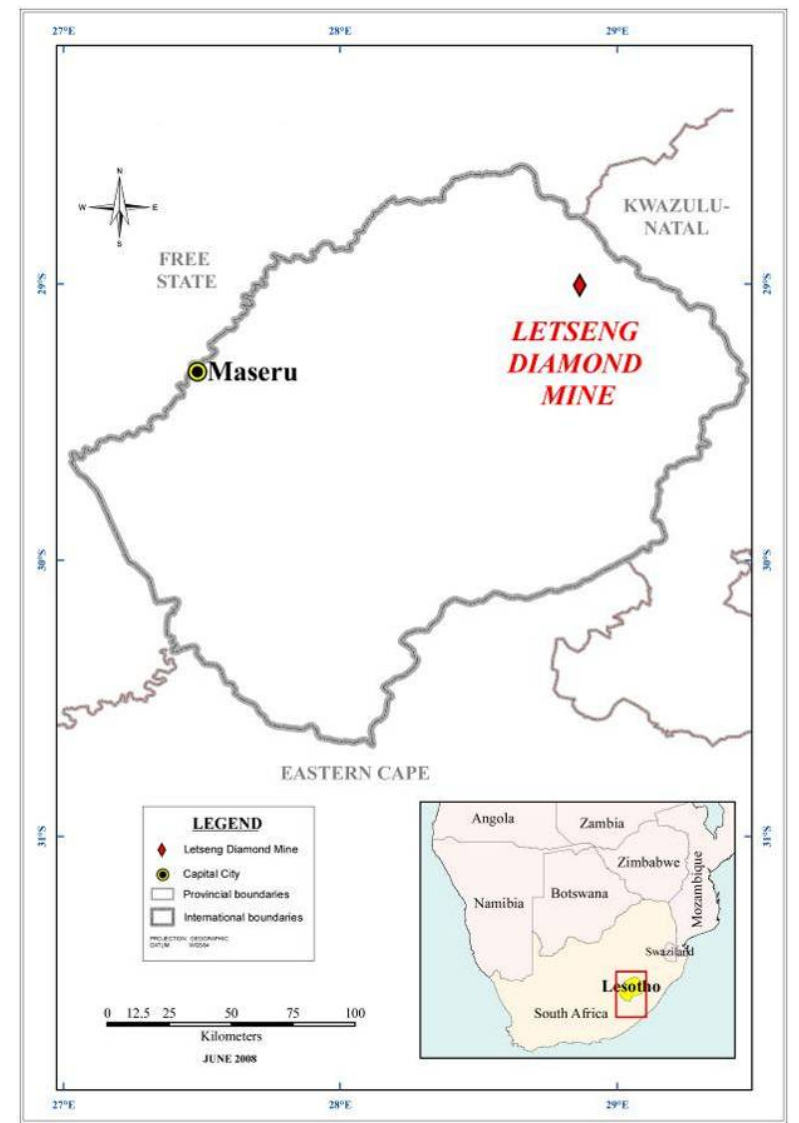

Figure 1. Locality map of the Letšeng Diamond Mine, Lesotho
When the recent phase of mining re-commenced, most of the effort was focused on the Satellite Pipe that previously had been excavated to a depth of c. $20 \mathrm{~m}$. Earlier work suggested that the Satellite Pipe was a tadpole-shaped body comprising one kimberlite type with variations in alteration and crustal xenolith content of the kimberlite (Bloomer and Nixon, 1973; Lock, 1980). However, the exposures provided by the recent mining, coupled with the advances in kimberlite emplacement theory since the 1980 s, provide an opportunity to re-evaluate the kimberlite facies and their influence on diamond distribution in the Satellite Pipe. We present our preliminary observations of the uppermost c. $70 \mathrm{~m}$ of the preserved Satellite Pipe that identify five volcaniclastic (VK) and one reworked volcaniclastic (RVK) facies rather than a single tuffisitic kimberlite breccia (TKB; Figure 2). These six facies are grouped into three zones: (i) southern zone with a marginal southern VK and a southern VK; (ii) northern zone with a marginal northern VK, a northern VK and a coarse northern VK; (iii) basalt raft related RVK.

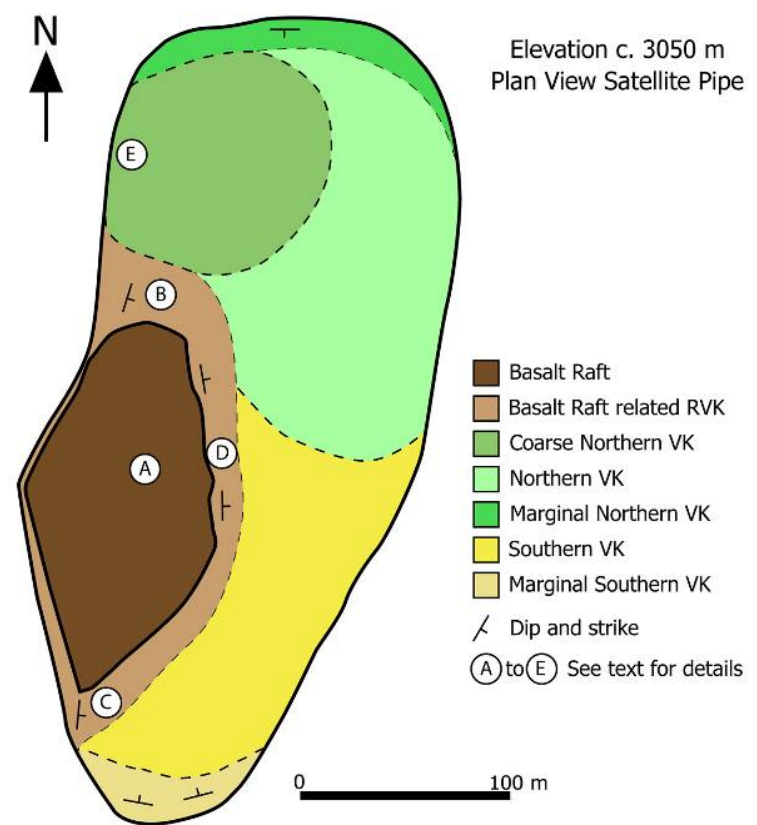

Figure 2. Plan view of six kimberlite facies identified in the uppermost $70 \mathrm{~m}$ of the Letšeng Satellite Pipe 
The Satellite Pipe is oval and not tadpole in shape, giving a slight increase in overall size from an initial 4.7 ha to 5.2 ha. The pipe has steep sides of $82^{\circ}-90^{\circ}$. A large basalt raft, c. $185 \mathrm{~m}$ long by c. $85 \mathrm{~m}$ wide and c. $220 \mathrm{~m}$ deep, is located along the western side of the Satellite Pipe which gave rise to the initial tadpole shape ('A' in Figure 2). However, recent mapping and drilling clearly shows kimberlite between the raft and the western in situ basalt wall (Figure 2).

Following the termination of the initial formal mining phase in 1982, the Satellite Pipe was subaerially exposed for c. 20 years effecting differential weathering of the upper layers of kimberlite such that internal structures were readily discernible in 2004. Crude layers dipping into the pipe from the western margin and off the eastern face of the basalt raft were the most commonly observed features (' $\mathrm{B}$ ' in Figure 2; Figure 3). This layering comprised a variety of coarser and finer grained RVK units with isolated lenses of basalt boulder breccia. Dip directions into the pipe varied from about $25^{\circ}$ on the northern side of the basalt raft to as steep as $65^{\circ}$ in front of this large block. Noteworthy was the recovery of the largest diamond found at Letšeng to date, the 603 ct Lesotho Promise, from a crudely-layered, coarse-grained breccia on the southern side of the basalt raft (' $\mathrm{C}$ ' in Figure 2).

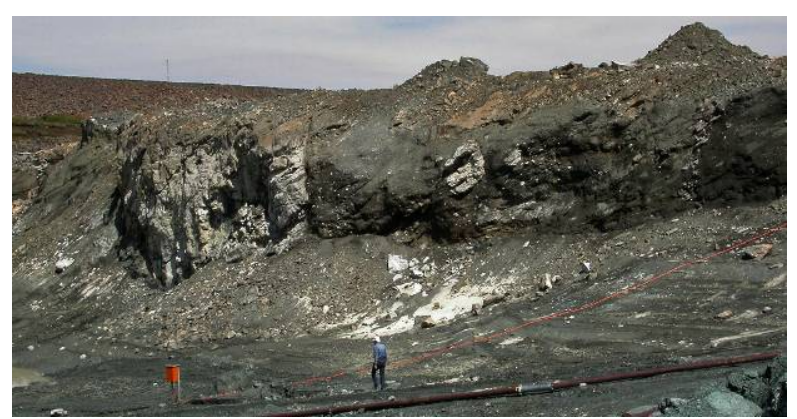

Figure 3. Layering along the western margin of the Satellite Pipe, adjacent to the northern contact of the basalt raft ('B' in Figure 2)

Of further interest, was the presence of sole marks on steeply dipping RVK beds surfaces in front of the basalt raft. These features are grooves and not slickensides and are believed to be caused by basalt boulders sliding into the pipe under the influence of gravity (' $D$ ' in Figure 2; Figure 4). Therefore the crudely bedded RVK and basalt breccia lenses are interpreted to be subaerial gravity and coarse talus deposits within the Satellite Pipe. These units have been grouped together as "basalt raft related RVK" that dominates the western side of the Satellite Pipe (Figure 2). Significantly, a greater proportion of coarser diamonds (up to $+50 \mathrm{ct}$ stones) were recovered from the basalt raft related RVK than from VK farther east into the pipe.

The VK occupying the northern sector of the Satellite Pipe is coarse grained, and contains kimberlite magmaclasts (ash, lapilli and bomb sizes), mantle xenoliths and thermally altered basalt xenoliths in a matrix of clean serpentine and microlitic clinopyroxene (figures 5 and 6). The kimberlite is distinguished by light grey thermally altered basalt, olive green olivines and speckled matrix. The kimberlite magmaclast types include irregular shaped autoliths, spherical cored juvenile magmaclasts with both thick and thin rims as well as spherical non-cored simple and multi-rimmed magmaclasts (figures 5 and 6). These magmaclasts range in size from less than $0.2 \mathrm{~mm}$ to at least $100 \mathrm{~mm}$. This VK is matrix supported but well packed.

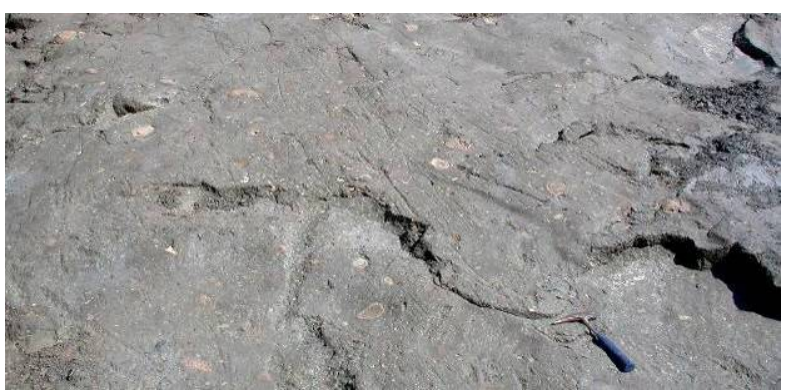

Figure 4. Sole marks on the layered RVK on the eastern margin of the basalt raft ('D' in Figure 2)

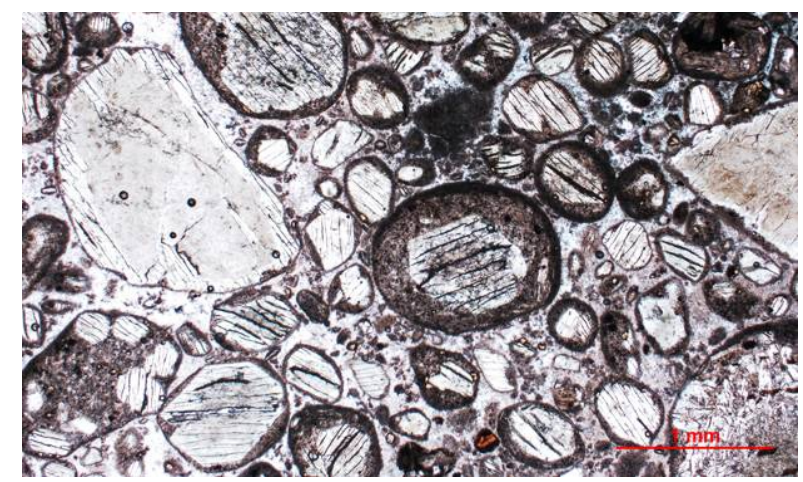

Figure 5. Photomicrograph of the northern VK facies showing kimberlite magmaclasts in a matrix of serpentine and microlitic clinopyroxene

In the northern zone VK, 3 facies are recognised based on variations in internal structure and grain size: a northern VK that is massive; a coarse northern VK that has significantly larger clasts and a greater abundance of very coarse mantle xenoliths; and a marginal northern VK that exhibits crude layering dipping into the pipe off the northern basalt sidewall (Figure 2).

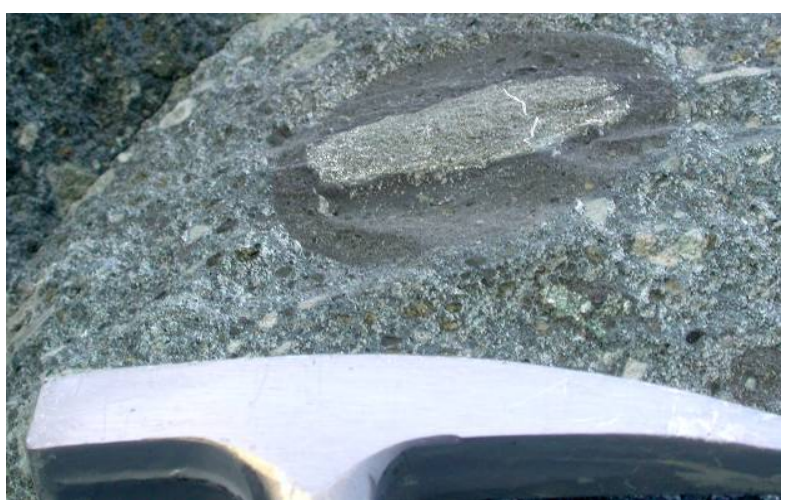

Figure 6. Kimberlite bomb in the coarse northern VK 
It is speculated that the $\mathrm{VK}$ in the northern zone has undergone fluidisation as described by Sparks et al. (2006). Evidence for this includes the serpentine and microlitic clinopyroxene matrix, the presence of gasrelease structures and the coarse nature of the overall grain size ('E' in Figure 2; Figure 7; Gernon et al., 2008). Variation seen within the northern VK facies is due to the degree of fluidisation, resulting in layered marginal zones and the highly mixed internal areas.

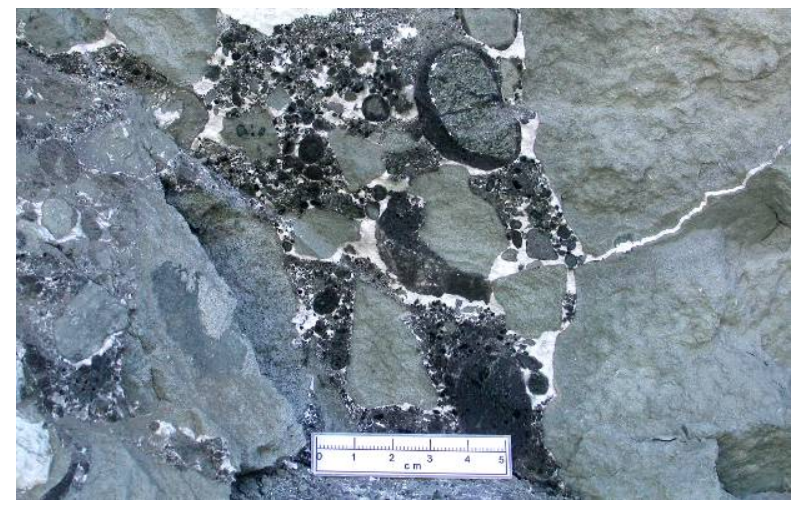

Figure 7. Close up of a gas-release structure in the coarse northern VK facies ('E' in Figure 2)

Although the overall grade rarely changes in the northern VK facies, the coarse northern VK has yielded more large $(+70 \mathrm{ct})$ diamonds than any of the other facies in the Satellite Pipe, including stones of $215 \mathrm{cts}$, 172 cts, 112 cts and 106 cts. This is attributed to the fluidisation process concentrating the larger clast sizes, notably kimberlite lapilli, kimberlite bombs and mantle-derived material (including diamond).

In the southern zone, two facies are recognised: a marginal southern VK and a southern VK (Figure 2). In general, the southern zone facies are finer grained than their northern counterparts and contain kimberlite magmaclasts and unaltered basalt xenoliths in a matrix of clay minerals, serpentine and microlitic clinopyroxene. The southern facies are distinguished by brown to dark grey basalt xenoliths and dark grey olivines in a brown to dark grey matrix (Figure 8). The southern VK is massive whereas the marginal southern $\mathrm{VK}$ is finely layered, dipping into the pipe at variable angles from $30^{\circ}$ to $80^{\circ}$ (Figure 2).

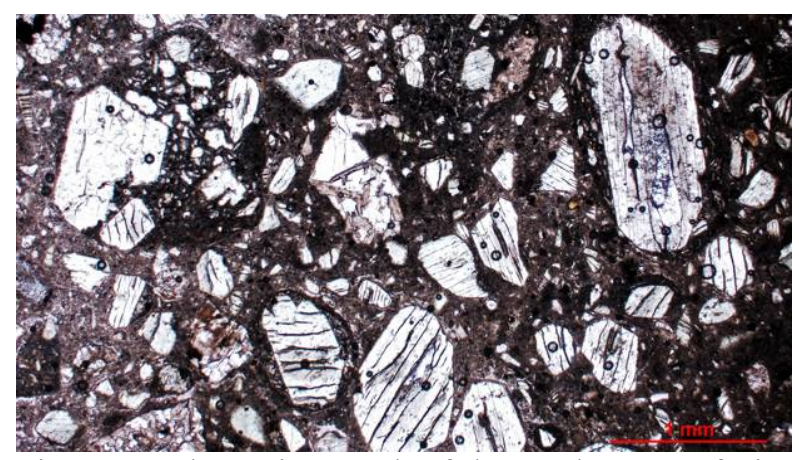

Figure 8. Photomicrograph of the southern VK facies showing olivines and magmaclasts in a matrix of clay, serpentine and microlitic clinopyroxene
The degree of fluidisation evident in the southern VK facies is considerably less than that displayed in the northern VK facies. Evidence for this includes the finer-grained nature of the kimberlite as well as the abundance of clay (alteration product of the original ash component) in the matrix. This indicates that much of the ash was not elutriated from the kimberlite in the southern half of the Satellite Pipe.

As with the northern facies, the grade in the finergrained southern units remains low. To date, no coarse (+70 ct) diamonds have been recovered from the southern facies which supports a growing correlation between grain size (in general, and across all clast types, specifically mantle xenoliths and kimberlite lapilli and bombs) and diamond size.

In contrast to earlier views that the Satellite Pipe comprises a simple TKB facies, our observations suggest a more complex emplacement history with penecontemporaneous explosive volcanic events and subaerial gravity-influenced deposition. Whilst grade appears to remain low in all 6 facies, larger diamonds are associated with coarse-grained VK that hosts abundant mantle xenoliths and kimberlite lapilli and bombs and also with gravity-influenced subaerial RVK on the western margin of the Satellite Pipe.

\section{References}

Bloomer, A.G. and Nixon, P.H., 1973. The geology of the Letšeng-la-Terae kimberlite pipes. In: Nixon, P.H. (Ed.), Lesotho Kimberlites, Lesotho National Development Corporation, Maseru, 20-36.

Bowen, D.C., Ferraris, R.D., Palmer, C.E. and Ward, J.D. (2008). On the Unusual Characteristics of the Diamonds from Letšeng-la-Terae Kimberlites, Lesotho. Extended Abstracts, $9^{\text {th }}$ International Kimberlite Conference.

Gernon, T.M., Sparks, R.S.J. and Field, M. 2008. Degassing structures in volcaniclastic kimberlite: examples from southern African kimberlite pipes. Journal of Volcanology and Geothermal Research, doi:10.1016/j.jvolgeores.2007.12.035

Lock, N.P. 1980. The geology of the Letseng Kimberlites, Lesotho. Unpublished $\mathrm{PhD}$ thesis, University of Sheffield.

Sparks, R.S.J., Baker, L., Brown, R.J., Field, M, Schumacher, J., Stripp, G. and Walters, A. 2006. Dynamical constraints on kimberlite volcanism. Journal of Volcanology and Geothermal Research, 155, 18-48.

Whitelock, T.K., Ward, J.D. and Smith, C.B., 2004. Letšeng kimberlite pipes, Lesotho: the highest diamond mine in the world re-opened. Geoscience Africa 2004, Abstract Volume, University of Witwatersrand, Johannesburg, South Africa, 704-706. 